\title{
Strategies Adopted by Airlines to Sustain Ticket Sales Performance Post the Zero Commission Policy: A Case of Kenya Airways (KQ)
}

\author{
Judy Kibe*, Hellen Ogutu, Wesley Kasanzu \\ School of Tourism, Hotel and Events Management, Moi University, Kenya
}

Received April 23, 2020; Revised February 24, 2021; Accepted March 12, 2021

\section{Cite This Paper in the following Citation Styles}

(a): [1] Judy Kibe, Hellen Ogutu, Wesley Kasanzu, "Strategies Adopted by Airlines to Sustain Ticket Sales Performance Post the Zero Commission Policy: A Case of Kenya Airways (KQ)," Universal Journal of Management, Vol. 9, No. 2, pp. 52 - 61, 2021. DOI: 10.13189/ujm.2021.090204.

(b): Judy Kibe, Hellen Ogutu, Wesley Kasanzu (2021). Strategies Adopted by Airlines to Sustain Ticket Sales Performance Post the Zero Commission Policy: A Case of Kenya Airways (KQ). Universal Journal of Management, 9(2), 52 - 61. DOI: 10.13189/ujm.2021.090204.

Copyright $\odot 2021$ by authors, all rights reserved. Authors agree that this article remains permanently open access under the terms of the Creative Commons Attribution License 4.0 International License

\begin{abstract}
The deregulation act has dramatically transformed the tourism distribution system since its inception in 1978. Deregulation act came up as a way to liberate the airline world from the entanglement of restrictive operating structure; this gave in the idea of cost cutting that negatively impacted the airlines and the travel agencies and slowly created a distribution gap. It also paved way to new operating environment; airline loss of goodwill among travel agents, introduction of low-cost no-frills carriers that tightened the competition cords, increased fuel prices and customer demands among others. The paper aimed at assessing the strategies adopted by Kenya Airways to sustain ticket sales post the zero commission policy. It specifically sought to establish the influence of yield management, internet and branding on determining ticket sales performance. The study employed survey design targeting Kenya airways sales staff and travel agents. The research instruments used were interviews and questionnaires. Descriptive statistics were used for data analysis. The results of the study established that Kenya airways depended on yield management in order to maintain their ticket sales management. The yield management strategy adopted includes focusing on corporate clients, price discrimination and cross selling. Further, internet with $60 \%$ presents the best alternative for airlines to bypass travel agencies in contacting their customers. Alliances such as sky team membership had also facilitated a large customer base for the airline. Kenya
\end{abstract}

Airways focuses on corporate travellers and takes advantage of the hub and spoke system provided by JKIA to reroute passengers from other destinations that use airlines that are in the Sky team Alliance. The study recommends incorporation of retail customers as equal contributors to its performance in air ticket sales.

Keywords Airlines, Strategies, Ticket Sales, Travel Agencies, Zero Commission Policy

\section{Introduction}

The airline industry remains one of the most capital-intensive ventures that is highly sensitive to social, political, and economic dynamics. Unlike other modes of transport that are mostly confined within the borders of a country, air travel's major reliance on cross-country routes if not trans-oceanic distances making it, a complex industry that is subject to the slightest of changes in prevailing social, political, and social conditions. Although air travel is the fastest means of travel, its safety is dependent on top of the range equipment, highly trained personnel, and rigorous procedures. Consequently, large amounts of initial capital investment is mandatory, which is succeeded by costly operational expenditures. Moreover, the concerns about the safety of the airline industry 
necessitated a highly regulatory environment in its formative years that only got relief with the passage of the Deregulation Act of 1978 in the United States of America (Robson, 1998).

Typical of many monopolies, the sustenance of a state-owned airline company is subject to fiscal challenges especially when operations of the company require high levels of maintenance. Therefore, the US government became the pioneer of the liberalization of the air industry with the passage of the Deregulation Act of 1978, which among other things, aimed to make the airline industry independent of government ownership, control, and supervision. More so, the objective was to increase competition in the sector through the abolishment of fixed price controls, entry, or exit barriers (NewMyer, 1990). In doing so, the US government wanted to wrestle the control of the airline industry from the IATA, which had become cartel like in its supervision of the industry. In addition, the US government wanted to encourage the growth of its airline industry beyond its borders by "exporting" the deregulation Act to other continents. Although this deregulation "export" was gradual, it was an eventual success after the European Union (EU) adopted it in 1987 however the rest of the World had fully adopted it by the mid-1990s (Robson, 1998).

Generally, the regulated environment contained many restrictions that included preordained destinations, plane capacity, flight frequency, and even cross-border fares that were acceptable to both countries after recommendation and approval by the International Air Transport Association (IATA) (Knorr \& Zigova, 2004). The deregulation of the airline industry revolutionized the sector bringing along several changes, with the travel agencies suffering the heaviest casualty (Borenstein and Rose, 2007). These changes include commission capping and commission cutting, broke the traditional relationship existing between airlines and travel agencies. In addition, the airline industry became open to all the players that included individuals, private companies, and the existing state-owned airlines (Button, 2008). Therefore, competition for customers intensified, which led many airlines to adopt cost-cutting measures that would make their operations sustainable if not profitable. Although reducing dependence on travel agencies or cutting links with them entirely proved relatively advantageous to airlines, they have been plagued with operational challenges that relate to the attraction, retention, and the full boarding of passengers in their flights (Brueckner and Spiller, 1991).

Due to the overreliance on travel agencies over long periods, many airlines or new entrants in any case find it hard to service passengers efficiently on their own without compromising their profit margins or alternatively, running at a loss (Amadeus, 2007). The travel agencies were the major drivers for the ticket sales of the airline companies and their negation after the deregulation Act has left many airlines struggling to fill their plane seats with passengers because of low numbers of ticket sales. Consequently, most of the airlines are adopting innovative if not radical measures to stay afloat in the airline industry (Schaur, 2006).

The Deregulation of Act of 1978 whose full adoption by African based airlines was evident by the late 1990s to early 2000s with commission caps and commission cuts to travel agencies has strained the once blooming symbiotic relationship between airlines and travel agencies (Zhang et al, 2009). In response, travel agencies have devised various mechanisms aimed at retaining their relevance to both the passengers and the airline companies that include the provision of services non-affiliated to ticket sales thus creating a distribution gap (Zhang and Wei, 1993). On the other hand, airline companies are striving to operate at a profit amidst a highly competitive environment provoked by the liberalization of the airline sector that motivated the entry of low-cost no-frills airline carriers: a threat to the incumbent legacy carriers.

Although these airlines previously managed to operate smoothly with the travel agencies doing the entire passenger procuring business, most of the airlines have found it a difficult job on their own. In fact, many airlines are operating at the threshold of survival and continuous loss making. Nevertheless, airline companies have adopted several initiatives that intend to revitalize their ticket sales capacity that include websites where potential customers can directly process their appointments. However, a subtle challenge exists. The long years of dependence on travel agents by airlines and experience of travel agencies endows them with a wealth of valuable customer information that is vital for the survival of airlines.

A majority of the studies conducted indicate that the airline industry focused on the airline -travel agencies relationship after the deregulation Act (Swan, 2007; US Dot, 1993; WTO 2006). Moreover, a significant number of studies have focused their investigation on the strategies that travel agencies have adopted in coping up with the effects of the deregulation Act (Schaur, 2006; Oum et al 2000)). However, previous research did not look at whether the strategies employed were helping the airlines to sustain or improve their ticket sales performance (Management, 2002) in relation to the zero commission policy. Although other studies have been conducted concerning the strategies employed by airlines in disintermediating travel agencies, most of the studies have focused on the individual strategies. Buhalis (2004) examined the strategic and tactical use of ICTs in the airline industry, though not specifying how the internet in particular influences ticket sales performance.

Besides, data from the airline industry reveal that despite the attempted alienation of travel agencies by airlines in ticket sales, the travel agencies still account for more than half of the ticket sales. Therefore, what 
mechanisms will the airline companies use to ensure they fair on their own, despite the apparent relevance of travel agencies that they attempting to bypass? This study intends to investigate the strategies adopted by a local based airline company, Kenya Airways, the country's "National Carrier," sustains its ticket sales performance amidst a depreciated reliance on travel agencies for passenger bookings and ticket sales. Objectives of the study included:

- Establish the influence of yield management on ticket sales

- Investigate how Kenya Airways (KQ) uses Internet to sustain its ticket sales

- Determine the influence of alliances on ticket sales performance

- Examine how Kenya Airways (KQ) enhances its brand to sustain ticket sales

\section{Theoretical Framework}

This study was anchored on Five Forces Theory and The theory of strategic turnaround. The five forces theory emphasizes on the five competitive forces that shape every industry and market. The forces include the new potential entrants, the power of suppliers and the power of buyers, threat of substitute, and the intensive competitive rivalry in the industry. The forces determine the intensity of competition hence attractiveness in an industry structure and performance as well as profitability which in turn prevents corporate decline. The model analyses the driving forces in an industry and allows organizations to access current strength in their competitive position and strength of the position they are planning to attain. This helps an organization to take advantage of its strengths and improve its weaknesses so as to compete efficiently (Porter, 1980). This theory emphasizes on the five forces model in the airline industry in Kenya, where notably, various forces have greatly affected the industry resulting to the corporate decline especially in the case of Kenya Airways. The industry has been affected by a host of external factors which include; high operating costs, high fuel prices, declining passenger traffic, landing and maintenance costs, intense competition from low cost carriers which has led to a great war in pricing and emergence of Covid-19 which brought operations of the airline to a halt thereby leading to corporate decline of Kenya airways (KQ, 2020).

The theory of strategic turnaround emphasizes on two types of turnaround strategies i.e. strategic and operating strategies. According to Hofer (1980), the operating turnaround are actions for firms suffering from inefficiency or threat of bankruptcy while the strategic turnaround actions applies to firms suffering from improper market alignment. The strategic turnaround choices take into consideration new ways to compete in the existing markets or entering new markets. Operating turnaround strategies on the other hand aim at coping with economic recession through cost cutbacks, increasing or generating revenues, reducing assets or a combination of the approaches as indicated in his classical framework for turnaround. Hofer (1980) further argues that the strategies reflect a different degree of severity of operating situation and the strategy involves cutbacks in discretionary expenses. It is employed by firms that operate below break-even point and need to increase their profitability. Asset reduction involves disposal of assets especially the fixed assets and is a last result solution for firms that operate far below break-even point. This reduces the level of fixed costs and helps in reducing total costs of the firm. Revenue enhancement is applied when a firm is operating substantially, but not extremely below break-even level which helps in generating extra revenue. If a firm is operating closer but below break-even levels, it calls for the application of a combination of strategies. Under this method, all the three that is, cost reduction, revenue generation and asset reduction actions, are pursued simultaneously in an integrated and balanced manner and, has favorable impact on cash flows and profits.

\subsection{Empirical Review}

The intent of the deregulation Act of 1978 was to liberalize the American airline industry. Initially, the sector was under restrictive regulation by the American government and supervision by the IATA. However, an increasing demand for air travel after World War II necessitated the relevant authorities to initiate measures that would eventually rid the sector controls that were making it a pseudo-monopoly and anti-competitive. The deregulation of the airline industry first got a foothold with the passage of the 1978 Act in the United States of America. Although the process has taken a long time to get adoption outside the USA, it has proven to be a double-edged sword to the airline industry. The passage of the 1978 Act ushered in a new environment for the airline industry that is characteristically market-driven by customer demand, freely competitive, and free of significant government control. In addition, Robson (1998) claims that the deregulation act ushered in an era that has witnessed the airline industry welcoming the free entry and exit of any type of operator as long as they met the minimum operating requirements. As a result, there has been increasing competition, growth in air travel, emergence of new and low cost carriers, and cheap travel options for passengers.

Cheung and Lam (2009) found out that prior to the deregulation Act, most of the airlines heavily relied on travel agencies for ticket sales in exchange for commissions. "A travel agent typically assumes four major responsibilities: information, reservations, distribution, and services". Most researchers acknowledge 
that many travel agencies specialize in the management of corporate travel expenses. In this way, they track and manage travel costs, ensure compliance of corporate policies, negotiate for special fare arrangements, and provide logistical information to companies. Prior to the implementation of the deregulation act, airlines employed parallel ticket distribution strategies to capture potential passengers. Then, the commission of travel agents was pegged at 10 percent of the ticket prices (Alamdari, 2002). Meanwhile, big travel agencies with a potential to meet carrier-established targets for market share received a separate override commission to motivate them increase sales for the airlines (Amadeus, 2007).

\subsection{Influence of Yield Management on Ticket Sales Performance}

Legacy airlines have found the current operating environment challenging with the entry of the "no frills" low-cost airlines. The built-up reputation of legacy airlines" "quality" over the years has accustomed passengers to particular minimum standards when on board and other "frills" even when the passengers are on heavily discounted Economy Class tickets. Therefore, yield management has become a very valuable tool that the legacy airlines employ.

A study conducted in 2004 by Knorr and Zigova to investiagte how airlines achieve the competitive edge through competitive value pricing strategies singled out yield management. Yield management relies on the selling of identical seats in the same class at different prices for revenue maximization (2004). It is essentially the control of seat availability and prices. It is noteworthy to recognize that the intense competition in the sector drove the adoption of yield management models that seek to capitalize on only a few seats that will determine the airline's profit or loss. However, the models are many and diverse that a full exploration of their working mechanisms is another paper entirely.

Nevertheless, several notable features of yield management warrant a mention. For instance, the concept of value pricing becomes demonstrable in the airline industry. The volatility in fuel prices forced airlines to prefer longer journey flights than shorter ones. The trend is because of the former guarantee high revenue that has been marred by high aircraft capital costs are spread per hour utilized. Moreover, airlines aim for more destinations because they guarantee that an aircraft' operational costs are spread over its design life. The two factors that are considerate of the load factor (ratio of revenue passenger kilometres (RPK) to the available seat kilometres (ASK), aptly named as the Break-even load factor (Brits, 2010).

Despite the reliance on volume sales to achieve a break-even load factor, the airline is a saturated market volume wise. Therefore, reliance on volume sales to increase revenue is a poor choice when compared to the exploitation of pricing strategies. Unlike other P's in the marketing mix, price is the only one that is not costly initially in generating revenue. Interestingly, a German consultancy firm, Simon, Kutcher, and Partners has demonstrated that even a 2 percent increase in price translates into a double-digit growth (Suau-Sanchez, Burghouwt, \&Fageda, 2010). Now, the concept of price discrimination becomes evident.

\subsection{Internet and Airline Ticket Sales Performance}

The reliance on conventional means of making ticket bookings and sales became obsolete with the advent of the internet. The internet and related technologies have continued to have an enthusiastic uptake by airlines because they increase the convenience of buying tickets for the passengers and simultaneously reduce the cost on ticket distribution cost for the airlines (Bin, 2013). In fact, nowadays airlines employing parallel distribution strategies have the propensity to rely more on internet bookings than selling their tickets through travel agents.

For instance, the passenger revenue generated from online bookings of Southwest Airlines increased from $65 \%$ in 2005 to $70 \%$ in 2006 (Ben-Yosef, 2007). A plausible explanation for this trend is that booking via the internet costs about $\$ 1$ while that of a travel agent is $\$ 10$. The continued and steady reliance on the internet as travel planning resources benefit airlines, who can create their own portals and websites that an airline's potential customers can easily and directly access. Apart from increasing sales, reducing coverage, and expanding the coverage of an airline's distribution system, the internet provides an airline with valuable data about demographics of their customers. This is in addition to helping the airline disintermediate the travel agents. In fact, many researchers attribute this as the major reason that airlines are striving to operate the web-based portals and websites (Irungu, 2012).

Interestingly, most airlines exploit the internet to offer promotional pricing information, online ticket auctions, or online special purchases while a significant number of seat booking and ticketing are still made through their sales shops or travel agents. According to researchers, one possible explanation of this hesitation by airlines to sell directly their tickets through their web portals is because airlines fear that the provision of airline tickets online is risky as competitors are likely to spy on its sales tactics through a website (Wensveen, 2010). Similarly, the direct access of customers to information about an airline's services on the web disadvantages them in their abilities to make a decision. For instances, issues regarding prices, types of packages, and travel suppliers 'policies often confuse customers. Therefore, many airlines have appointed select travel agencies to offer consultancy services. It should be noted that there has been a steady rise of exclusively internet based travel agents who are 
responding to this shortcoming.

In addition, airlines are devising and exploiting new methods of ticket distribution such as ticketless services, which involves the issuance of boarding passes to passengers instead of tickets (Pompl, Schuckert, \&Möller, 2007). Amadeus has forecasted that the future of the airline industry would be characterized by many airlines employing electronic and internet based platforms to bypass travel agents when contacting and selling tickets to potential passengers. Similarly, CAP strategic research (2011) has statistically projected an increasing acceptance and willingness of passengers to directly book flights either through the airlines' web portals or through online travel agents. The only shortcoming of these two research bodies is their deficit in explaining what means the airlines will employ to circumvent their heavy reliance on travel agents to distribute their tickets. Figure 1 is illustrative of how airline travel will be booked in the future.
A casual examination of the web portal operated by Kenya Airways demonstrates the usefulness of the website at informing the airline's customers. For instance, the website advertises the dates when fare discounts are available. In addition, information about the fleet of the airline, the destinations the airline travels to, flight statuses, flight bookings, booking modifications, online check-ins, and on-board offerings are provided to the passengers (Kenya Airways, 2014). Conclusively, the website of Kenya Airways is performing the same function as convectional travel agents. The only significant advantage offered by the website over convectional travel agents is that it offers ubiquity to passengers in terms of accessing the services and product offerings of the airline. It should be noted that the website is multi-lingual to accommodate the different audiences found all over the world. The English and French language are particularly used on the website.

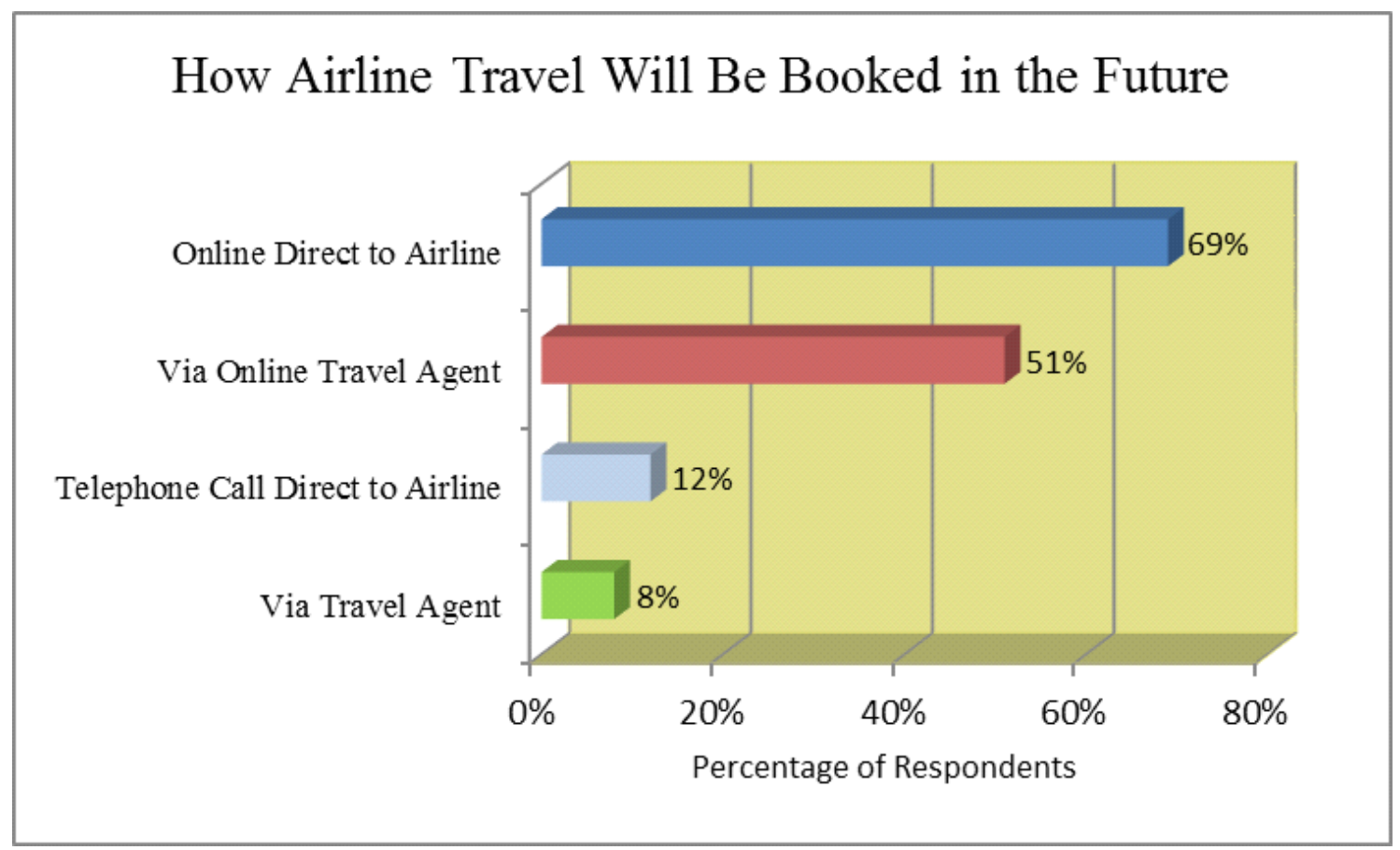

Source: CAP Strategic Research, 2011

Figure 1. The potential of online travel booking 


\subsection{Influence of Alliances on Ticket Sales Performance}

The main business of airline carriers is the transportation of passengers to and from their destinations by air. However, the primary concern of airlines' management teams is the sales performance of their airlines. Although airlines have to engage in other activities that include marketing, maintenance of their aircraft fleets, and provision of hospitality services to their passengers, all of these efforts are aimed at the sustenance and improvement of their sales performance. Increased competition in the airline industry that was borne out of the liberalization of the industry necessitated many airlines to reconsider their sales strategies and cost containment. According to Goll, Johnson and Rasheed (2007), several authors and experts in the airline sector agree that the stakeholders in the flight business need to adapt to the highly dynamic nature of the business environment lest they become outdated and phased out. Some of the experts include Keynes (2009), Bissessur and Alamdari (1998), and Bunz and Maes (1998). All these authors stress the need for players to be fast in responding to changes in the industry that has a multidimensional dynamism.

\subsection{Branding and Ticket Sales Performance}

Branding is very important if not the first tool useful in increasing an airline's survival and chances of profitability. Branding involves a myriad of factors that include image building, relationship marketing, and persistent employee retraining to update them on emergent issues in the industry (Kato, 1999). Image building entails the building of reputation and brand name that is easily identifiable and appealing to potential customers. World recognized brands like Mercedes Benz, Rolex, Apple Inc., and Marriot Hotels have built their reputation by providing high quality and exceptional products and services that are hardly imitated because they were created with extraordinary effort. This way, a brand name is able to accrue market share dominance that gives it an advantage over its rivals in terms of sales performance (Pot, 2013). The airline industry is very sensitive to externalities.

Therefore, any event that affects the reputation of an airline despite it having built up a successful image over the years has an instant effect on its appeal. A more recent and suitable example is the Malaysian Airline. Although the one accident and the disappearance of two of its aircrafts in a period of five months are still undergoing investigations, pilot error or management problems in all these two cases cannot be ruled out. Consequently, these two incidences have seen the airline's fortunes greatly affected to the extent some of its planes have been grounded because passengers are avoiding boarding its aircrafts (MacLeod, 2014).

Relationship marketing provides another strategic tool for airlines to employ. This tool entails that an airline is proactive in determining customer needs and engaging them accordingly (Pot, 2013). The level of success at this front for an airline is determined not only by the strategic response, but also by the speed of the responses. Excellent customer service guarantees a least expensive means of marketing the company's service offerings because it creates a symbiotic relationship between the passenger and the airline carrier. Ticket sales, like all selling activities, employ the four steps to achieve favourable results. These four sequential steps include attention, interest, desire, and action (Pot, 2013).

It is prudent that the staff of an airline establish excellent relationship with potential customers so that these four sequential processes can be achieved. Moreover, relationship marketing is better placed at exploiting differential pricing by the identification of the most profitable customer to allow the airline to customize its marketing and advertising mix so that the correct target market is captured. This is in addition to the customer centricity and advocacy approaches that help the airline realize a customer's true needs in the process of aiding the customer find the best air travel package (Wensveen, 2010). Generation of income from passengers through non-flying activities like commissions for connecting car-rentals and hotel room reservations are also constituents of relationship marketing.

\section{Methodology}

The study utilized survey research design targeting Kenya airways sales staff and travel agents. Being a heterogeneous group, stratified random sampling and systematic sampling were used to ensure fair representation of the group. The sample size for the study was 100 respondents to whom interviews and questionnaires were administered for the purposes of data collection. In sampling, the study used a 5\% level of precision and a confidence level of $95 \%$. This is because surveys based on a random sample of respondents are subject to sampling error. Descriptive statistics was used to analysis data.

Independent variables for the study included yield management strategies, branding, the use of internet technologies, and alliances. These are variables that are independent of third parties like travel agencies. In this case, the manner in which Kenya Airways will employ each strategy will determine the performance of its ticket sales. Although the government and fuel prices intercede the relationship as moderating and intervening variables, the performance of the ticket sales of Kenya Airways is dependent on how the airline will adjust its implementation of the four independent variables and how long restriction measures implemented during the COVID-19 pandemic will continue be in effect, since the 
COVID-19 pandemic has had a significant impact on the air transportation system worldwide.

\section{Finding and Discussions}

The paper aimed at assessing the strategies adopted by Kenya Airways to sustain ticket sales post the zero commission policy. It specifically sought to establish the influence of yield management, internet and branding on determining ticket sales performance. Kenya Airways has devised several ways to increase the ticket sales post the zero commission policy. The study established that yield management $(70 \%)$ and alliances $(68 \%)$ are the trendiest strategies utilized to increase the ticket sales performances. This section further discusses the strategies adopted in detail.

\subsection{Yield Management}

The study sought to establish the influence of yield management on ticket sales. Associated with these strategies included price discrimination based on customer type, volume sales, overbooking option and cross-selling and up-selling. Price discrimination based on passenger type is the method that Kenya Airways heavily relies on to sustain its ticket sales. In this case, many respondents pointed out corporate clients as the most preferred at $(61 \%)$. Implying that corporate clients are influencing the performance of KQ. Cross- selling and up selling with $(57 \%)$ are the strategies that provide the second means of revenue sustenance as shown in Table 1. This trend can be related to the fact that cross selling and up-selling are often used in situations where corporate travellers are involved. Amadeus (2013) also noted that cross selling and up selling of products in airlines as useful yield management tactic in airlines. The yield management tactic is useful in helping the airline yield maximum revenue from each flight operated. It helps in control of seat availability and prices for revenue maximization. The tactic also capitalizes on a few seats that determine the airline's profits or loss.

\subsection{Use of Internet Technologies}

The use of the internet technologies is highly discordant. Although it is difficult to obtain real data from the customers themselves, the perception they relay to travel agents and the data that employees of Kenya Airways provide point to a higher internet use for accessing tickets information among travellers. According to Kenya Airways (2014), their website advertises the dates when fare discounts are available. In addition, information about the fleet of the airline, the destinations the airline travels to, flight statuses, flight bookings, booking modifications, online check-ins, and on-board offerings are provided to the passengers. Therefore, majority respondents (60\%) agreed that more customers use the internet to access ticket information. However, most customers still use physical ticket selling points than company's website to make most of their purchases (58\%) as shown in Table 1. These results imply that, much as the airline has made is possible for passengers to book their tickets online, some passengers still prefer to do it manually Wensveen (2010) noted airlines hesitated to sell their tickets directly through their web portals because airlines fear that the provision of airline tickets online is risky as competitors are likely to spy on its sales tactics through a website Similarly, the direct access of customers to information about an airline's services on the web disadvantages them in their abilities to make a decision. For instances, issues regarding prices, types of packages, and travel suppliers 'policies often confuse customers. Therefore, many airlines have appointed select travel agencies to offer consultancy services.

\subsection{Alliances}

Alliance is another trendy strategy adopted by Kenya Airways with most respondents (86\%) confirming that the airline sustains its ticket sales performance through the exploitation of the JKIA as its hub and spoke network point. Additionally the airline benefits from its membership in the Sky Team Alliance. 57\% of the respondents substantiated that the passengers from the airplanes in the Sky Team Alliance use the Kenya Airways planes to re-route to destinations that Kenya Airways alone can fly as shown in Table 1. Alliances allow the carriers to share codes, routes, and slots in order to break into different air transport markets.

\subsection{Brand Enhancement}

It is evident that Kenya Airways performs poorly in all its brand enhancement strategies. For example, most respondents strongly agreed that most customers complained its bad in-flight customer service (53\%). Furthermore, its reliability at schedule maintenance is disapproved at an overall rate of $46 \%$. 
Table 1. Strategies Associated Parameters

\begin{tabular}{|c|c|c|c|c|c|}
\hline All Survey Responses & $\begin{array}{c}\text { Strongly } \\
\text { Agree } \\
\% \\
\end{array}$ & $\begin{array}{l}\text { Agree } \\
\%\end{array}$ & $\begin{array}{c}\text { Neutral } \\
\%\end{array}$ & $\begin{array}{c}\text { Disagree } \\
\%\end{array}$ & $\begin{array}{c}\text { Strongly } \\
\text { Disagree } \\
\%\end{array}$ \\
\hline $\begin{array}{l}\quad \text { Yield Management } \\
\text { Price discrimination based on customer type. } \\
\text { Volume sales of tickets } \\
\text { Overbooking option } \\
\text { Cross-selling and Up-selling }\end{array}$ & $\begin{array}{c}61 \\
31 \\
7 \\
57\end{array}$ & $\begin{array}{l}17 \\
30 \\
13 \\
15\end{array}$ & $\begin{array}{l}- \\
3 \\
- \\
-\end{array}$ & $\begin{array}{l}14 \\
24 \\
24 \\
20\end{array}$ & $\begin{array}{c}8 \\
12 \\
56 \\
8\end{array}$ \\
\hline $\begin{array}{l}\text { Branding } \\
\text { Excellent in-flight customer service than competitors } \\
\text { Reliability in schedule maintenance } \\
\text { Response to customers' requests for change of flights promptly } \\
\text { Most customers applaud its service and value the Kenya Airways } \\
\text { brand over other brands }\end{array}$ & $\begin{array}{l}15 \\
20 \\
13 \\
23\end{array}$ & $\begin{array}{l}10 \\
13 \\
12 \\
15\end{array}$ & $\begin{array}{l}- \\
- \\
15 \\
11\end{array}$ & $\begin{array}{l}22 \\
21 \\
28 \\
14\end{array}$ & $\begin{array}{l}53 \\
46 \\
32 \\
28\end{array}$ \\
\hline $\begin{array}{l}\text { Use of Internet Technology } \\
\text { Customers are using the internet more than physical locations to }\end{array}$ & 20 & 40 & - & 40 & - \\
\hline $\begin{array}{l}\text { More tickets sold through the physical avenues than the company's } \\
\text { websites }\end{array}$ & 58 & 33 & - & 9 & - \\
\hline $\begin{array}{l}\text { Ticket prices are cheaper on the website than the physical selling } \\
\text { points }\end{array}$ & 37 & 34 & - & 15 & 14 \\
\hline Most customers inquire about ticket prices indicated on the website & 60 & 20 & - & 7 & 13 \\
\hline The website is reliable throughout the day and night & 2 & 13 & - & 20 & 65 \\
\hline $\begin{array}{l}\text { Alliances } \\
\text { Surpasses rivals in rerouting most passengers from other airlines to } \\
\text { destinations within Africa }\end{array}$ & 57 & 21 & 5 & 17 & - \\
\hline $\begin{array}{l}\text { Dominate in the acquisition of local customers as its hub and spoke } \\
\text { network point }\end{array}$ & 68 & 10 & - & 4 & - \\
\hline It connects to most international destinations than its competitors & 26 & 11 & 5 & 22 & 36 \\
\hline
\end{tabular}

\section{Conclusions}

The study concludes that Kenya Airways relies essentially on two factors to maintain its air ticket sales performance; in particular, these factors include yield management and alliances. The study established that Kenya Airways' yield management strategies were tailored to meet the corporate customers. Kenya Airways brand perception among the corporate was the single factor making it attract clients. It's identity as the "National Carrier" endeared it to corporate clients. Kenya Airways heavily depends on the JKIA as a hub and spoke network system to reroute passengers from other airlines to regional and international destinations that Kenya Airways has exclusive landing rights. Further, Kenya Airways benefits from its membership in the Sky Team alliance by getting access to international destinations that rival companies do not have. Incidentally, the airline takes advantage of the inability of other airlines to fly to some destinations by appropriating the passengers who use the JKIA as a connection hub. Although internet technologies present the best alternative for airlines to bypass the travel agencies in contacting and selling air tickets, the study recognized that Kenya Airways website was preferred only as source of information however, most customers still used physical ticket selling points such travel agencies to make most of their purchases. In relation to branding, Kenya Airways' in-flight customer service and the activity of its sales representatives were found wanting hence, rival companies are effectively exploiting this avenue to ensure they have high air ticket sales.

Finally, the study concludes that the COVID-19 pandemic has caused an unprecedented crisis for Kenya Airways just as it has impacted other airlines across the world. Most governments around the globe have imposed travel bans, lockdowns, and shutdowns to enforce social distancing measures in their efforts to prevent further rapid spread of the disease and to safeguard the effectiveness of national healthcare systems. It is expected that continued ban on travels due to the COVID-19 crisis will see Kenya Airways ticket sales revenues drop even further in 2021 depending on when the vaccine will reach the country. This estimate is based on a scenario with severe travel restrictions lasting many months and it could even be worse, with extended restrictions or, in the case of a new virus outbreak, even new restrictions. Therefore, the study recommends incorporation of retail customers as equal contributors to the airline performance in air ticket sales.

The study also recommends that since the COVID-19 pandemic has upset performance of tickets for KQ, there is need for the airline to rethink pricing to fill nonstop flights, potentially reducing the nonstop premium and thereby undercutting demand for connecting flights operating on the same route. This study contributes to the Five Forces Theory which emphasizes on the five competitive forces that shape every industry and market. The forces include the new potential entrants, the power 
of suppliers and the power of buyers, threat of substitute, and the intensive competitive rivalry in the industry. The forces determine the intensity of competition hence attractiveness in an industry structure and performance as well as profitability which in turn prevents corporate decline. Based on the findings, the strategies adopted by KQ to Sustain Ticket Sales Performance must be able to take into account the forces that affect the industry such as Covid-19 pandemic. The study will also be important for the future researchers and academicians who will use the findings of this study as a point of reference.

\section{REFERENCES}

[1] Alamdari, F. (2002). Regional Development in Airlines and Travel Agents Relationship. Journal of Air Transport Management, 339-348.

[2] Amadeus. (2007). Service Fees and Commission Cuts. Amadeus: Amadeus IT Group SA.

[3] Amadeus. (2013). Amadeus business model and highlights 2013. Madrid: Amadeus.

[4] Ben-Yosef, E. (2007). The Evolution of the US Airline Industry: Technology, Entry, and Market Structure -Three Revolutions. Journal of Air Law and Commerce, 305-349.

[5] Bin, S. (2013). Adoption of buy airline ticket online in Malaysia.

[6] Borenstein, S. and Rose, N.L., (2007), How Airline Markets Work...or do they? Regulatory Reform in the Airline Industry, NBER Working Paper 13452

[7] Brits, A. (2010). A Liberalised South African Airline Industry: Measuring Airline Total-Factor Productivity. Journal of Transport and Supply Chain Management, 22-38.

[8] Button, K. (2008). The Impacts of globalization on International Air Transport Activity. International Transport Forum. Mexico.

[9] Brueckner, J.K. and Spiller, P.T. (1991), Competition and Mergers in Airline Networks, International Journal of Industrial Organization, 9, 323-342.

[10] Cheung, R., \& Lam, P. (2009). How Travel Agency Survive in e-Business World? Communications of the IBIMA, 85-92.

[11] Cosmas, A., Belobaba, P., \& Swelbar, W. (2008). Framing the Discussion on Regulatory Liberalization: A Stakeholder Analysis of Open Skies, Ownership and Control. Cambridge: MIT International Center for Air Transportation.

[12] Hall, A., Sheik, A., \& Schwartz, D. (2008). The Delta-Northwest Merger. Minneapolis: Nexus.

[13] Hofer, C. W. (1980). Turnaround strategies. Journal of business strategy.

[14] IBM Global Business Services. (2010). Airlines 2020: Substitution and commoditization: Two developments the global airline industry can no longer afford to ignore. New York: IBM Institute for Business Value.
[15] Irungu, I. W. (2012, August 07). Influence of Information and Communication Technology on Performance of Aviation Industry - A Case of Kenya Airways Ltd. Master's Research project. Nairobi, Nairobi, Kenya: University of Nairobi.

[16] Kato, V. N. (1999, August 18). The Effect of Customer Service on Sales in Passenger Air Transport: A Case Study of Uganda Airlines. Dissertation. Kampala, Uganda: Makerere University.

[17] Kenya Airways. (2013). Q 2012-13 Half Year Investors Brief. Nairobi: Kenya Airways.

[18] Knorr, A., \& Zigova, S. (2004). Competitive Advantage Through Innovative Pricing Strategies: The Case of the Airline Industry. Bremen: Universitat Bremen.

[19] Meersman, H., Voorde, E. V., \& Vanelslander, T. (2008). The Air Transport Sector after 2010: A Modified Market and Ownership Structure. European Journal of Transport and Infrastructure Research, 71-90.

[20] Morrell, P. (2008). Can long-haul low-cost airlines be successful? Research in Transportation Economics, 61-67.

[21] National Commission to Ensure Consumer Information and Choice in the Airline Industry. (2002). The Travel Agency System Today. Washington, D.C.: National Commission to Ensure Consumer Information and Choice in the Airline Industry.

[22] NewMyer, D. A. (1990). The Impact of Deregulation on Airports: An International Perspective. The Journal of Aviation/Aerospace Education \& Research, 59-79.

[23] Oum, T.H., Park, J.H., and Zhang, A. (2000). Globalization and Strategic Alliances: The Case of

[24] The Airline Industry (Elsevier Science, 2000), 229 pages. ISBN 008 o43596 3. Accessible from http://www.elsevier. $\mathrm{nl}$

[25] Pompl, W., Schuckert, M., \& Möller, C. (2007). The Future of Small and Medium Sized Airlines in Europe. New York: Springer Publishing.

[26] Pot, T. (2013, September 26). Changing the game: A different approach on customer marketing at KLM Royal Dutch Airlines. Master Thesis. Twente, Denmark: University of Twente.

[27] Porter, M. E. (1980). Competition in the open economy: A model applied to Canada (No. 150). Harvard University Press.

[28] Robson, J. E. (1998). Airline Deregulation: Twenty Years of Success and Counting. Regulation, 17-22.

[29] Rutner, S. M., \& Brown, J. H. (1999). Outsourcing as an Airline Strategy. Journal of Air Transportation World Wide, 22-31.

[30] Schaur, G. (2006), Airplanes and Price Volatility, mimeo, Purdue University.

[31] Schlumberger, C. E. (2010). Open Skies for Africa: Implementing the Yamoussoukro Decision. Washington, D.C.: The World Bank.

[32] Suau-Sanchez, P., Burghouwt, G., \&Fageda, X. (2010). 
Determinants for seat capacity distribution in EU and US, 1990-2009. Barcelona: University of Barcelona.

[33] Swan, W. (2007), Misunderstandings about Airline Growth, Journal of Air Transport Management 13, pp.3-8.

[34] US DOT, (1993), The Airline Deregulation Evolution Continues: The Southwest Effect, Office of Aviation Analysis, US Department of Transportation.

[35] Wensveen, J. (2010). The Airline Industry: Trends, Challenges, Strategies. Leadership and Policy Seminar Series (pp. 1-49). Sydney: The University of Sydney, Faculty of Economics and Business.
[36] World Trade Organisation (WTO) (2006), Second Review of the Air Transport Annex: Developments in the Air Transport Sector (Part Two) Quantitative air services agreements review (QUASAR), Volumes I and II Note by the Secretariat, document S/C/W/270/Add.1".

[37] Zhang, A. and Wei, X. (1993), Competition in Airline Networks: The Case of Constant Elasticity Demands. Economics Letters, 42, 253-259.

[38] Zhang, A., Hanaoka, S., Inamura, H. and Ishikura, T. (2009), Low Cost Carriers in Asia: Deregulation, Regional Liberalization and Secondary Airports, Research in Transport Economics, Vol. 17, forthcoming. 58826.12.JGT 